\title{
STRATEGI ALTERNATIF PENINGKATAN ANGKA PARTISIPASI MAHASISWA PENDIDIKAN JARAK JAUH DI UPBJJ - UT GORONTALO
}

\author{
Raflen Aril Gerungan, Diki, Muhammad Husni Arifin \\ Universitas Terbuka (UT) Jakarta, Indonesia \\ Email: raflenaril@ecampus.ut.ac.id, dikinian@ecampus.ut.ac.id, mhusni@ecampus.ut.ac.id
}

Received: 2020-08-15; Accepted: 2020-08-05; Published: 2020-09-15

\begin{abstract}
Abstrak
Tujuan penelitian untuk menganalisis dan merumuskan strategi alternatif kegiatan sosialisasi promosi layanan pendidikan jarak jauh dalam meningkatkan angka partisipasi mahasiswa di UPBJJ UT Gorontalo. Responden dalam penelitian ini berjumlah 24 orang dipilih dengan teknik Purposive Sampling. Analisis data penelitian menggunakan sustainability Strength Weakness Opportunity Threath (SWOT) dan analisis Quantitative Strategic Planning Matrix (QSPM). Dari 12 (dua belas) strategi alternatif yang diperoleh dari hasil analisis matriks SWOT dan matriks QSPM didapat 5 (lima) strategi alternatif prioritas yang dapat menjadi acuan dalam melakukan kegiatan sosialisasi dan promosi. Kelima strategi alternatif tersebut adalah kegiatan sosprom dengan konten yang menarik melalui internet dan media sosial, pelibatan alumni didalam melakukan kegiatan soprom di lapangan sehingga menciptakan nilai tambah, mengedukasi masyarakat secara konsisten dan berkelanjutan tentang semua informasi Universitas Terbuka, setiap kegiatan sosprom perlu adanya pengumpulan informasi nomor handphone yang akan dijadikan database untuk tindak lanjut kepada calon mahasiswa, perlu adanya kegiatan peningkatan kapabilitas kepada tim yang melakukan kegiatan sosprom.
\end{abstract}

Kata Kunci: angka partisipasi; pendidikan jarak jauh; promosi; sosialisasi; strategi

\begin{abstract}
This study aims to analyze and formulate alternative strategies for distance learning socialization and promotion activities in order to increase the participation rate of students in UPBJJ UT Gorontalo. There are 24 students as respondents, determined by purposive sampling technique. The data were analyzed using sustainability Strength Weakness Opportunity Threat (SWOT) and Quantitative Strategic Planning Matrix (QSPM). The results of the SWOT and QSPM analysis showed that 5 out of 12 alternatives strategies have become the key strategies that can be implemented in the socialization and promotion activities. Those five key strategies are conducting socialization and promotion on internet and social media using attractive contents, involving alumni in the socialization and promotion activities to get more value added, educating society with comprehensive information about UT consistently and continuously, collecting of prospective students' phone number during the socialization and promotion activities for database and follow-up purpose, and enhancing the capability of team in conducting the socialization and promotion activities.
\end{abstract}

Keywords : participation rate; distance learning; promotion; socialization; strategy 


\section{PENDAHULUAN}

UT sebagai perguruan tinggi yang menerapkan sistem pembelajaran secara jarak jauh memiliki visi menjadi institusi Pendidikan Tinggi Terbuka dan Jarak Jauh (PTTJJ) berkualitas dunia. Sebagai institusi Pendidikan Tinggi Negeri (PTN), UT dalam memberikan layanan pendidikan jarak jauh kepada mahasiswa pengoperasiannya didukung oleh 39 kantor Unit Program Belajar Jarak Jauh (UPBJJ) yang tersebar di Indonesia dan satu kantor Pusat Pengelolaan Mahasiswa Luar Negeri, sehingga UT mampu melakukan penetrasi penjangkauan dan penyebaran pendidikan tinggi (Puspa, Unde, \& Bahfiarti, 2014) \& (Husain, 2020). Dalam proses perjalanan waktu, layanan UT tidak terlepas dari tantangan yang berpengaruh terhadap proses pembelajaran yang bersifat akademik (kualitas) dan berpengaruh terhadap jumlah masukan mahasiswa (kuantitas). Menurut data Indeks Kepuasan Masyarakat (IKM) UT tahun 2017 menunjukkan bahwa terdapat peningkatan kategori dari memuaskan ke sangat memuaskan dari hampir semua aspek dan indikator penilaian apabila dibandingkan dengan tahun 2016 (Zulfaton \& Krisnanto, 2017).

Salah satu bentuk tantangan UT sebagai institusi PTTJJ adalah bagaimana cara meningkatkan jumlah angka partisipasi mahasiswa di era Revolusi Industri 4.0 yang tidak lain merupakan revolusi digital dalam menjembatani manusia dengan dunia cyber. Beberapa perguruan tinggi di luar UT telah mulai melakukan tranformasi pembelajaran dari tatap muka ke pembelajaran online walaupun persentasinya relatif kecil, tujuannya untuk meningkatkan angka partisipasi mahasiswanya. (Irwansyah, 2018) menyatakan bahawa dalam rangka meningkatkan Angka Partisipasi Kasar (APK) pemerintah telah melakukan terobosan dengan diperbolehkannya perguruan tinggi (selain Universitas Terbuka/UT) untuk menyelenggarakan Pendidikan Jarak Jauh (PJJ), kebijakan tersebut tertuang pada Peraturan Menteri Pendidikan dan Kebudayaan Nomor 24 Tahun 2012 tentang Penyelenggaraan Pendidikan Jarak Jauh pada Perguruan Tinggi.

Untuk mempengaruhi Lembaga pendidikan tinggi oleh calon mahasiswa citra positif institusi juga bisa digunakan sebagai instrument positioningnya (Ayuni \& Mulyana, 2015) karena citra perguruan tinggi memberikan pengaruhi signifikan terhadap tingkat kepercayaan dan loyalitas mahasiswa pada institusi perguruan tinggi (Aghaz, Hashemi, \& Sharifi Atashgah, 2015) misalnya dengan memberikan ucapan pada laman media sosial Universitas (Kilgarriff \& Renau, 2013).Namun UT bukan lagi satu-satunya perguruan tinggi yang memberikan layanan pembelajaran secara jarak jauh atau pembelajaran online. Di sisi lain UT menargetkan jumlah mahasiswa jika memungkinkan harus mencapai satu juta mahasiswa, hal ini tentunya menjadi tantangan secara tersendiri yang bersifat positif, karena dapat menjadi acuan untuk dapat bergerak lebih maju. Unit Program Belajar Jarak Jauh (UPBJJ) sebagai kepanjangan tangan UT di daerah harus dapat menganalisis strategi kegiatan sosialisasi dan promosi (Sosprom) layanan pendidikan jarak jauh yang relevan sehingga mampu menjawab tantangan-tantangan di atas dan kebutuhan pasar pendidikan jarak jauh di daerah. 


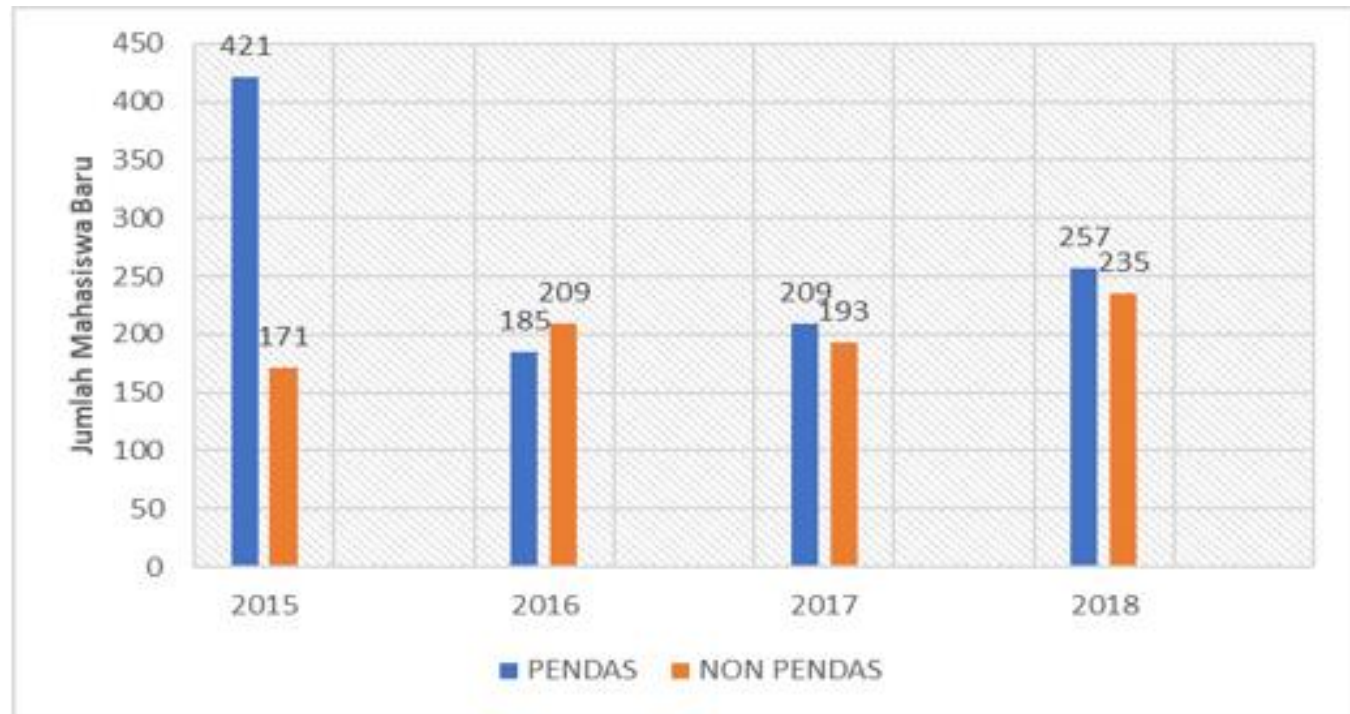

Sumber: data diolah (sipelapor.ut.ac.id, 2019)

\section{Gambar 1}

Diagram jumlah mahasiswa baru pertahun UPBJJ-UT Gorontalo.

UPBJJ UT Gorontalo merupakan salah satu ujung tombak UT di Provinsi Gorontalo. Data jumlah mahasiswa baru masuk di UPBJJ UT Gorontalo untuk Pendidikan Dasar (Pendas) dan Non Pendidikan Dasar (Non Pendas) dapat dilihat pada gambar 1 (satu). Data tersebut sebagai sampel yang menunjukkan bahwa pada mahasiswa Pendas mengalami penurunan dalam jangka per 4 (empat) tahun terakhir (2015-2018), namun terlihat masih ada kenaikan untuk jangka per tahunnya $(2016,2017$, \& 2018) tapi belum signifikan. Penurunan mahasiswa Pendas disebabkan oleh banyaknya guru-guru yang sudah memiliki gelar S1 pendidikan, kurangnya minat untuk masuk pada program sarjana pendidikan karena daya tarik masuk ke perguruan tinggi lain baik negeri maupun swasta, dan ketidakmampuan guru-guru berumur untuk menggunakan teknologi dalam pembelajaran online. Sebaliknya pada mahasiswa baru Non Pendas terlihat memiliki tren peningkatan jumlah mahasiswa baru untuk jangka per 4 (empat) tahun, walaupun ada penurunan sedikit pada tahun 2017. Peningkatan mahasiswa Non Pendas dipengaruhi penguatan kerjasama dengan mitra baik pemerintah daerah dan instansi pemerintah lainnya (Polda, Kemenkumham, dan Intansi di bawah Kemenkeu) dan mahasiswa baru generasi milenial yang melek teknologi.

Secara keseluruhan terlihat jumlah mahasiswa di UPBJJ UT Gorontalo masih stagnan dan ada kecenderungan mengalami penurunan. Jumlah mahasiswa yang masuk dapat dipengaruhi oleh faktor-faktor tertentu lainnya. Faktor tersebut berupa menurunnya keaktifan dari pengurus kelompok belajar (pokjar) pada setiap kabupaten/kota, tingkat pengenalan masyarakat umum terhadap UT, persaingan dengan perguruan tinggi baik negeri maupun swasta, dan kemampuan ekonomi masyarakat. Menjaga keseimbangan dan peningkatan jumlah mahasiswa baru maka UPBJJ UT Gorontalo melakukan beberapa kegiatan sosprom layanan pendidikan jarak jauh sebagai kegiatan kunci untuk melakukan penetrasi ke masyarakat. Kegiatan dan strategi sosprom pada UPBJJ UT Gorontalo seperti berkunjung langsung pada instansi, promosi pada car free day, penggunaan media konvensional (koran dan radio), penggunaan media sosial internet (facebook dan Instagram), dan sosprom oleh pengurus kelompok berlajar (Pokjar). Kegiatan sosprom di atas diharapkan mampu menjaga 
keseimbangan dan peningkatan angka partisipasi mahasiswa baru secara signifikan, karena sesuai data jumlah mahasiswa pada 4 (empat) tahun terakhir masih tetap mengalami fluktuatif. (Wandari, 2013) menyatkan kegiatan promosi berkaitan dengan penyebaran informasi yang memiliki manfaat untuk meningkatkan pengetahuan calon mahasiswa terhadap sistem perkuliahan, pembiayaan, dan program studi yang ditawarkan.

Adapun tujuan penelitian untuk menganalisis dan merumuskan strategi alternatif kegiatan sosprom layanan pendidikan jarak jauh dalam meningkatkan angka partisipasi mahasiswa di UPBJJ UT Gorontalo. Manfaat yang diharapkan dari hasil penelitian adalah: Memberikan rekomendasi kepada pimpinan kantor UPBJJ UT Gorontalo tentang strategi alternatif kegiatan sosprom layanan pendidikan jarak jauh yang mampu meningkatkan angka partisipasi mahasiswa di era Revolusi Industri 4.0.

\section{METODE}

Penelitian dilaksanakan pada bulan September - November 2019 di Kantor Unit Pelaksana Belajar Jarak Jauh (UPBJJ) - Universitas Terbuka (UT) Gorontalo. Metode dalam penelitian ini adalah metode survey. Responden yang terlibat dalam penelitian ini berjumlah 24 orang dengan 13 orang dari staf UPBJJ-UT Gorontalo dan 11 orang dari pengurus kelompok belajar yang aktif melakukan kegiatan sosialisasi dan promosi layanan pendidikan jarak jauh di wilayah kerja UT Gorontalo. Responden dipilih dengan menggunakan teknik Purposive Sampling (Sugiyono, 2017). Pengumpulan data pada penelitian ini adalah sebagai berikut: Data primer diperoleh melalui wawancara semi terstruktur, observasi, dan kuisioner. Data sekunder diperoleh dari berbagai publikasi ilmiah (jurnal) dan data yang dipublikasikan oleh instansi atau lembaga terkait. Analisis data pada penelitian ini meliputi tiga tahapan. Tahap pertama adalah tahap input dengan menganalisis faktor-faktor internal dan eksternal. Tahap kedua adalah tahap analisis dengan matriks SWOT untuk mencari strategi alternatif. Tahap ketiga adalah tahap keputusan menggunakan analisis QSPM untuk menentukan urutan strategi alternatif yang telah dihasilkan tahap sebelumnya, dari strategi terbaik sampai yang terendah melalui pembobotan (Adamu \& Shakantu, 2016)\& (Metzger, Del Pino, Prowitt, Goodward, \& Perrara, 2012).

\section{HASIL PENELITIAN DAN PEMBAHASAN}

\section{Analisis Matriks SWOT.}

Analisis SWOT dipergunakan untuk merumuskan strategi alternatif dalam kegiatan sosialisasi dan promosi peningkatan angka partisipasi mahasiswa di UPBJJ-UT Gorontalo, berikut matriks analisis SWOT pada penelitian ini: 


\section{Tabel 1}

Analisis Matriks SWOT

Peluang (Opportunity)

/Ancaman (Threat)
Kekuatan (Strength) /Kelemahan (Weakness)

Kekuatan (S)

1. Materi sosprom yang 1. Kurangnya tindak lanjut pada disampaikan menarik dan calon mahasiswa setelah bagus dilakukan kegiatan sosprom

2. Pendanaan dan fasilitas 2 . kegiatan sosprom yang baik

3. Penggunaan media sosial, media online, dan 3. Pengurus pokjar kurang media lainnnya dalam beriklan

4. Sumber Daya Manusia 4. (SDM) UT yang memadai dalam kegiatan sosprom

5. Membangun relasi atau 5. Metode sosprom di lapangan bekerjasama dengan stakeholders setempat

Peluang $(\mathrm{O})$

1. Pemanfaatan media sosial dan online dalam kegiatan sosprom

2. Terbukanya kesempatan kerjasama stakeholders dengan

3. Bergesernya paradigma pemanfaatan teknologi oleh masyarakat

4. Meningkatnya populasi milenial

generasi

5. Hadirnya Alumni dan lulusan UT di daerah

\section{Strategi S-O}

1. Intensifikasi yang bersifat inovasi dan kreatif melaui pemanfaatan media sosial dan media pendukung lainnya. (S1, S2, S3, O1, O3, O4)

2. Kolaborasi tim sosprom dan Alumni UT ke lapangan Kantor-Kantor (Sekolah, Pemerintah/Swasta, \& Kelompok Masyarakat) (S1, S2, S4, O4, O5)

3. Memperkuat meningkatkan jumlah kerjasama dengan para pemangku kebijakan yang ada di setiap daerah. (S2,S4,S5,O2,O5)

\section{Strategi W-O}

maksimal lagi dalam kegiatan sosprom (tiga tahun terakhir) Informasi tentang UT kepada masyarakat umum masih minim

masih kaku informasi tentang UT masih

Pemanfaatan teknologi informasi dalam melakukan tindak lanjut kepada calon mahasiswa (W1, O1, O3)
Melibatkan alumni yang berdomisili pada daerah- daerah yang akan dilaksanakan kegiatan sosprom (W2, W4,O4,O5)

Memberikan stimulus pada pengurus pokjar dan alumni UT dalam setiap perekrutan mahasiswa baru (W3, W2, O3, O4)

dan 4. Meningkatkan intensitas penyebaran informasi yang terukur baik lewat media sosial, media online, dan berkunjung langsung kelapangan $(\mathrm{W} 4,01,03,04)$

5. Mengedukasi tim tentang metode sosprom kekinian dengan memanfaatkan media online sebagai sumber materi. (W5, O1)

\section{Ancaman (T)}

\section{Strategi S-T}

\section{Strategi W-T}

1. Hadirnya tawaran perguruan tinggi lain dengan program pembelajaran seperti UT (kelas jarak jauh)

2. Tingkat pengetahuan

1. Melakukan kepada tentang program, dan layanan di UT dengan metode yang menarik dan mudah edukasi 1. Membangun database calon mahasiswa dan melakukan pengecekan serta memberikan informasi rutin kepada (W1,W4,T1,T2) 


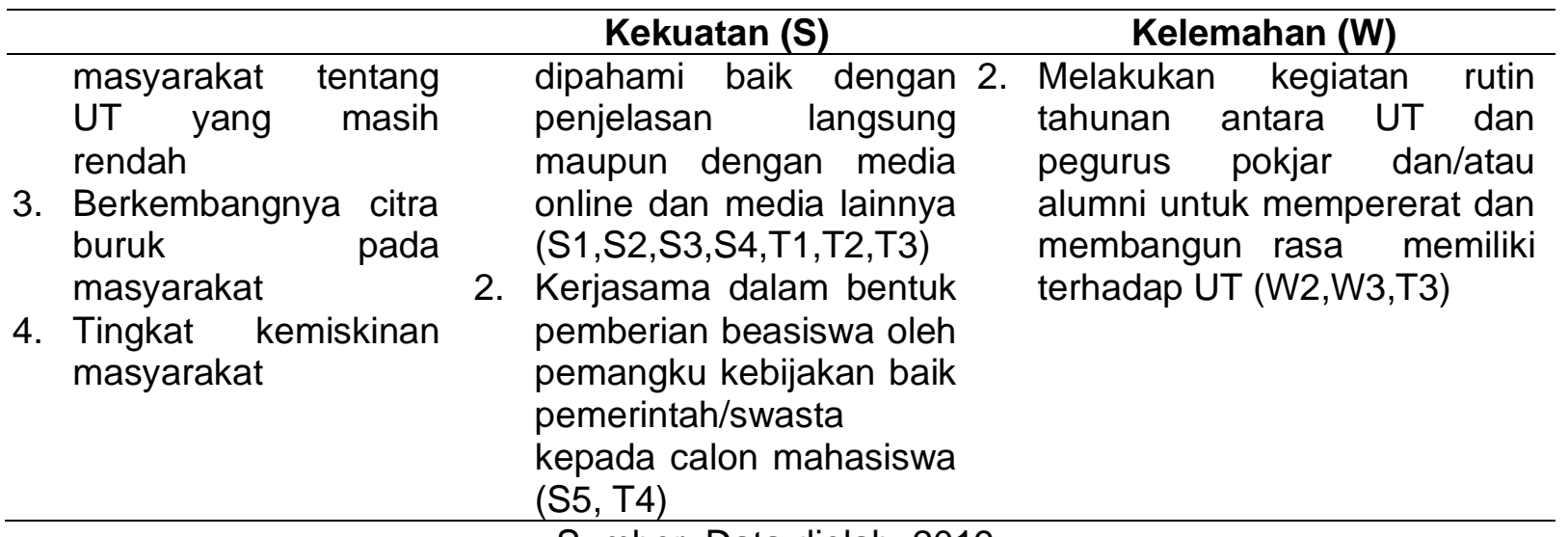

Sumber: Data diolah, 2019.

Berdasarkan analisis matriks SWOT pada tabel 1 di atas maka didapat beberapa strategi alternatif:

1. Intensifikasi sosprom yang bersifat inovasi dan kreatif melaui pemanfaatan media sosial dan media pendukung lainnya. (S1, S2, S3, O1, O3, O4)

2. Kolaborasi tim sosprom dan Alumni UT ke lapangan (Sekolah, Kantor-Kantor Pemerintah/Swasta, \& Kelompok Masyarakat) (S1, S2, S4, O4, O5)

3. Memperkuat dan meningkatkan jumlah kerjasama dengan para pemangku kebijakan yang ada di setiap daerah. (S2, S4, S5, O2, O5)

4. Melakukan edukasi kepada masyarakat tentang pembiayaan, program, dan layanan di UT dengan metode yang menarik dan mudah dipahami baik dengan penjelasan langsung maupun dengan media online dan media lainnya (S1, S2, S3, S4, T1, T2,T3)

5. Kerjasama dalam bentuk pemberian beasiswa oleh pemangku kebijakan baik pemerintah/swasta kepada calon mahasiswa (S5, T4)

6. Pemanfaatan teknologi informasi dalam melakukan tindak lanjut kepada calon mahasiswa (W1, O1, O3)

7. Melibatkan alumni yang berdomisili pada daerah-daerah yang akan dilaksanakan kegiatan sosprom (W2, W4, O4, O5)

8. Memberikan stimulus pada pengurus pokjar dan alumni UT dalam setiap perekrutan mahasiswa baru (W3, W2, O3, O4)

9. Meningkatkan intensitas penyebaran informasi yang terukur baik lewat media sosial, media online, dan berkunjung langsung kelapangan (W4, O1, O3, O4)

10. Mengedukasi tim tentang metode sosprom kekinian dengan memanfaatkan media online sebagai sumber materi. (W5, O1)

11. Membangun database calon mahasiswa dan melakukan pengecekan serta memberikan informasi rutin kepada mereka (W1, W4, T1, T2)

12. Melakukan kegiatan rutin tahunan antara UT dan pegurus pokjar dan/atau alumni untuk mempererat dan membangun rasa memiliki terhadap UT (W2, W3, T3)

2. Analisis Quantitative Strategic Planning Matrix (QSPM).

Pemilihan strategi alternatif menggunakan analisis Quantitative Strategic Planning Matrix (QSPM), dimana QSPM merupakan alat analisis yang mengorganisir informasi kualitatif dan kuantitatif, serta hasil analisis QSPM juga berdasarkan dari kemenarikan alternatif-alternaitf strategi yang ada. Hasil analisis QSPM untuk strategi alternatif pada kegiatan sosialisasi dan promosi peningkatan angka partisipasi mahasiswa dapat dilihat pada tabel 2 di bawah ini.

\section{Tabel 2}


Urutan Hasil Analisis QSPM Startegi Alternatif Sosialisasi dan Promosi.

\begin{tabular}{|c|c|c|}
\hline Urutan & Strategi & $\begin{array}{l}\text { Nilai } \\
\text { TAS }\end{array}$ \\
\hline 1 & $\begin{array}{l}\text { Intensifikasi sosprom yang bersifat inovasi dan kreatif melaui } \\
\text { pemanfaatan media sosial dan media pendukung lainnya. }\end{array}$ & 12.7 \\
\hline 2 & $\begin{array}{l}\text { Meningkatkan intensitas penyebaran informasi yang terukur baik } \\
\text { lewat media sosial, media online, dan berkunjung langsung } \\
\text { kelapangan. }\end{array}$ & 12.6 \\
\hline 3 & $\begin{array}{l}\text { Kolaborasi tim sosprom dan Alumni UT ke lapangan (Sekolah, } \\
\text { Kantor-Kantor Pemerintah/Swasta, \& Kelompok Masyarakat) }\end{array}$ & 12.5 \\
\hline 4 & $\begin{array}{l}\text { Melakukan edukasi kepada masyarakat tentang pembiayaan, } \\
\text { program, dan layanan di UT dengan metode yang menarik dan } \\
\text { mudah dipahami baik dengan penjelasan langsung maupun dengan } \\
\text { media online dan media lainnya }\end{array}$ & 11.6 \\
\hline 5 & $\begin{array}{l}\text { Membangun database calon mahasiswa dan melakukan } \\
\text { pengecekan serta memberikan informasi rutin kepada mereka }\end{array}$ & 11.6 \\
\hline 6 & $\begin{array}{l}\text { Pemanfaatan teknologi informasi dalam melakukan tindak lanjut } \\
\text { kepada calon mahasiswa }\end{array}$ & 11.3 \\
\hline 7 & $\begin{array}{l}\text { Melibatkan alumni yang berdomisili pada daerah-daerah yang akan } \\
\text { dilaksanakan kegiatan sosprom }\end{array}$ & 10.1 \\
\hline 8 & $\begin{array}{l}\text { Mengedukasi tim tentang metode sosprom kekinian dengan } \\
\text { memanfaatkan media online sebagai sumber materi. }\end{array}$ & 10.0 \\
\hline 9 & $\begin{array}{l}\text { Memberikan stimulus pada pengurus pokjar dan alumni UT dalam } \\
\text { setiap perekrutan mahasiswa baru }\end{array}$ & 9.4 \\
\hline 10 & $\begin{array}{l}\text { Melakukan kegiatan rutin tahunan antara UT dan pegurus pokjar } \\
\text { dan/atau alumni untuk mempererat dan membangun rasa memiliki } \\
\text { terhadap UT }\end{array}$ & 8.7 \\
\hline 11 & $\begin{array}{l}\text { Memperkuat dan meningkatkan jumlah kerjasama dengan para } \\
\text { pemangku kebijakan yang ada di setiap daerah. }\end{array}$ & 8.3 \\
\hline 12 & $\begin{array}{l}\text { Kerjasama dalam bentuk pemberian beasiswa oleh pemangku } \\
\text { kebijakan baik pemerintah/swasta kepada calon mahasiswa }\end{array}$ & 7.7 \\
\hline
\end{tabular}
Sumber: Data diolah, 2019.

Berdasarkan tabel 2 di atas, di dapat 5 strategi alternatif prioritas yang dapat menjadi acuan dalam melakukan kegiatan sosialisasi dan promosi untuk meningkatakan angka partisipasi mahasiswa di UPBJJ-UT Gorontalo. Strategi alternatif prioritas tersebut adalah: 1. Intensifikasi sosprom yang bersifat inovasi dan kreatif melalui pemanfaatan teknologi informasi dan komunikasi (media internet, media sosial dan media pendukung lainnya), 2. Kolaborasi tim sosprom dan Alumni UT ke lapangan (Sekolah, Kantor-Kantor Pemerintah/Swasta, \& Kelompok Masyarakat), 3. Melakukan edukasi kepada masyarakat secara konsisten tentang pembiayaan, program, dan layanan di UT dengan metode yang menarik dan mudah dipahami baik dengan penjelasan langsung maupun dengan media online dan media lainnya, 4. Membangun database calon mahasiswa dan memanfaatkan teknologi informasi komunikasi dalam melakukan tindak lanjut, 5. Kegiatan peningkatan kapabilitas metode sosprom yang kekinian kepada tim sosprom secara kontinu.

\section{KESIMPULAN}

Raflen Aril Gerungan/ Strategi Alternatif Peningkatan Angka Partisipasi Mahasiswa Pendidikan Jarak Jauh Di UPBJJ - UT Gorontalo 
Dengan diadakannya pelatihan Edukasi Kesiapan Belajar Mandiri (EKBM) maka mahasiswa sangat terbantu dalam mempelajari modul. Mereka menjadi lebih tahu cara belajar yang lebih baik. Untuk kedepannya pelatihan Edukasi Kesiapan Belajar Mandiri (EKBM) tetap dipertahankan karena sangat membantu mahasiswa dalam mempelajari modul.

\section{REFERENSI}

Adamu, Anita Dzikwi, \& Shakantu, Winston M. (2016). ) Strategic Maintenance Management Of Built Facilities In An Organisation.

Aghaz, Asal, Hashemi, Amin, \& Sharifi Atashgah, Maryam S. (2015). Factors Contributing To University Image: The Postgraduate Students' Points Of View. Journal Of Marketing For Higher Education, 25(1), 104-126.

Ayuni, Devi, \& Mulyana, Andy. (2015). Pengaruh Faktor-Faktor Pembentuk Loyalitas Mahasiswa Universitas Terbuka. Jurnal Manajemen Dan Organisasi, 6(3), 225-242.

Husain, Samiun. (2020). Kontribusi Belajar Jarak Jauh Mahasiswa Tinggal Di Desa Terpencil. Aksara: Jurnal Ilmu Pendidikan Nonformal, 5(2), 103-110.

Irwansyah, Irwansyah. (2018). Penyelenggaraan Sistem Pendidikan Tinggi Jarak Jauh Di Perguruan Tinggi Swasta. Jas-Pt (Jurnal Analisis Sistem Pendidikan Tinggi Indonesia), 2(1), 39-50.

Kilgarriff, Adam, \& Renau, Irene. (2013). Estenten, A Vast Web Corpus Of Peninsular And American Spanish. Procedia-Social And Behavioral Sciences, 95, 12-19.

Metzger, Eliot, Del Pino, Samantha Putt, Prowitt, Sally, Goodward, Jenna, \& Perrara, A. (2012). Sswot: A Sustainability Swot. Washington, Dc: World Resources Institute.

Puspa, Yuyun Yunita, Unde, Andi Alimuddin, \& Bahfiarti, Tuti. (2014). Strategi Promosi Dalam Menjaring Calon Mahasiswa Baru Pada Upbjj-Ut Palu Di Wilayah Propinsi Sulawesi Tengah. Kareba: Jurnal IImu Komunikasi, 281-288.

Sugiyono. (2017). Metode Penelitian Kuantitatif, Kualitatif, Dan R\&D. Bandung.

Wandari, R. (2013). Implementasi Strategi Promosi Dalam Bauran Pemasaran Terhadap Peningkatan Jumlah Mahasiswa Pada Upbjj-Ut Pekanbaru.

Zulfaton, Zulfaton, \& Krisnanto, Aditya Budi. (2017). Evaluasi Pelayanan Publik Dan Kinerja Aparat Terhadap Kepuasan Masyarakat Di Kelurahan Dadaprejo Kota Batu. Jurnal Manajemen Jayanegara, 9(2), 115-140. 